\title{
PENDEKATAN KETERAMPILAN DALAM PEMBELAJARAN BAHASA ARAB
}

\author{
Muna Nabila Amatullah, Novi Kusumaningrum \\ Universitas Islam Negeri Sunan Kalijaga Yogyakarta \\ email: munanabilaamatullah@gmail.com
}

\begin{abstract}
The approach is an essential part of language teaching. This is a way of looking at teaching and learning. One of the techniques of Arabic language teaching is the Integrated Skills Approach. This approach combines four language skills in the learning process. This study aims to describe the mastery approach and its implementation in learning Arabic. The method used in this research is a descriptive qualitative method. The data in this study were collected through library research. Based on the study results, it was found that using the integrated skills approach in learning Arabic will train students in the use of language in its entirety and naturally, which includes receptive and productive language activities. Because in real life these four skills are not used separately.
\end{abstract}

Keywords: Approach; Integrated Skills Approach; Language Skill.

\begin{abstract}
Abstrak
Pendekatan merupakan bagian penting dalam pembelajaran bahasa. Hal ini terkait dengan bagaimana pengajar memandang sebuah proses pembelajaran. Salah satu pendekatan dalam pembelajaran bahasa Arab adalah pendekatan keterampilan. Pendekatan ini terfokus pada keempat keterampilan berbahasa yang tidak dipisahkan dalam proses pembelajaran. Penelitian ini bertujuan untuk mendeskripsikan pendekatan keterampilan dan implementasinya dalam pembelajaran bahasa Arab. Metode yang digunakan dalam penelitian ini adalah metode kualitatif deskriptif. Data-data dalam penelitian ini dikumpulkan melalui studi kepustakaan. Berdasarkan hasil penelitian didapatkan bahwa menggunakan pendekatan keterampilan dalam pembelajaran bahasa Arab akan melatih peserta didik dalam penggunaan bahasa secara utuh dan alami yang
\end{abstract}


meliputi kegiatan berbahasa reseptif dan produktif. Karena dalam kehidupan sehari-hari keempat keterampilan tersebut tidak digunakan secara terpisah.

Kata Kunci: Keterampilan Berbahasa; Pendekatan; Pendekatan Keterampilan.

\section{A. Pendahuluan}

Bahasa adalah sistem lambang bunyi yang dipergunakan oleh para anggota suatu masyarakat untuk bekerja sama, berinteraksi, dan mengidentifikasi diri. ${ }^{1}$ Sedangkan berbahasa adalah menggunakan bahasa. Penggunaan bahasa erat kaitannya dengan keterampilan berbahasa. Dalam istilah Arab keterampilan bahasa dapat disepadankan dengan istilah mahārah al-lughawiyah. Fatkhi Ali Yunus mendefinisikan mahärah lughawiyah sebagai kegiatan reseptif bahasa yang ditunjukkan dalam membaca dan mendengar, dan kegiatan produktif yang ditunjukkan dalam berbicara dan menulis. Yunus juga menambahkan bahwa kedua sisi tersebut diikuti oleh kegiatan berpikir. ${ }^{2}$

Keterampilan berbahasa terdiri dari 4 (empat) aspek, yaitu menyimak (Istimā'), berbicara (kalām), membaca (qirā'ah), dan menulis (kitābah). Keempat aspek tersebut hendaknya dikuasai oleh para pembelajar bahasa khususnya bahasa Arab, guna mencapai kemahiran berbahasa Arab. Dalam proses pembelajaran bahasa Arab, keempat keterampilan tersebut diupayakan untuk dikuasai oleh peserta didik dengan disesuaikan dengan teori masing-masing mahārah. Misalnya keterampilan menyimak dengan teori pembelajaran menyimak, keterampilan berbicara dengan teori pembelajaran muhadatsah, keterampilan membaca dengan teori pembelajaran membaca, dan keterampilan menulis dengan teori pembelajaran menulis. ${ }^{3}$

Namun dalam prakteknya, keempat keterampilan berbahasa tersebut dipisahkan satu sama lain, seakan-akan keempatnya berdiri sendiri. Keindependenan ini akan memberikan dampak yang kurang baik bagi proses pembelajaran. Karena pada dasarnya keempat keterampilan bahasa tersebut terhubung dan saling mempengaruhi satu sama lain. Pembelajaran bahasa asing yang hanya terfokus pada satu keterampilan berbahasa saja akan membatasi peserta didik dalam meningkatkan kemampuan berbahasanya. Pada hakikatnya keempat keterampilan tersebut dalam kehidupan sehari-hari digunakan tidak secara terpisah. Dengan demikian, memisahkan keempat

\footnotetext{
${ }^{1}$ Harimurti Kridalaksana, Kamus Linguistik (Jakarta: PT Gramedia, 2008), 24.

${ }^{2}$ Fatkhi Ali Yunus dalam Ahmad Abdul Audh, Madakhil Ta'limul Lughah AlArabiyyah (Makkah Al-Mukarramah: Jami'ah Umm Al-Qura, 2000), 41.

${ }^{3}$ Maksudin dan Qoim Nurani, Pengembangan Kurikulum Pembelajaran Bahasa Arab (Teori dan Praktik) (Yogyakarta: Lesfi, 2018), 97.
} 
keterampilan bahasa tersebut sama dengan menghalangi peserta didik untuk bisa lebih dekat dengan penggunaan bahasa yang sesungguhnya.

Penelitian ini membahas tentang pendekatan keterampilan yang meliputi definisi, kekurangan dan kelebihannya serta implikasinya dalam pembelajaran bahasa Arab. Metode yang digunakan dalam penelitian ini adalah metode kualitatif deskriptif, dimana data-data yang terkait dikumpulkan melalui studi kepustakaan.

Adapun penelitian sebelumnya terkait tema ini adalah penelitian Hakan Aydoğan yang membahas tentang (1) perlu atau tidaknya pengajaran bahasa Inggris (sebagai bahasa kedua) menggunakan pendekatan Intergreted Skill; (2) ada atau tidaknya pengaruh perbedaan gender terhadap perbedaan peningkatan kemampuan peserta didik. Dari penelitian ini didapatkan hasil bahwa, pendekatan Intergreted Skill perlu digunakan dalam pengajaran bahasa Inggris, karena dapat menghadapkan peserta didik pada penggunaan bahasa secara asli dan menghadapkan mereka pada tantangan untuk menggunakan bahasa secara natural. Perbedaan gender tidak mempengaruhi secara signifikan dalam meningkatkan kemampuan peserta didik. ${ }^{4}$

Nasr D. Abdrobo dalam penelitiannya menyatakan bahwa keempat keterampilan berbahasa; listening, reading, speaking, dan writing tidak boleh dipisahkan. Karena keempatnya saling berhubungan satu sama lain. Sedangkan pembelajaran bahasa yang berasumsi bahwa keempatnya adalah bagian-bagian terpisah akan membatasi motivasi dan ketertarikan peserta didik terhadap kegiatan belajar bahasa. Abdrobo juga menambahkan bahwa sangat tidak mungkin mengajarkan peserta didik untuk membaca tanpa peran menulis, berbicara, dan mendengar. ${ }^{5}$

Adapun penelitian ini bertujuan untuk mendeskripsikan bagaimana pendekatan keterampilan (Al-Madkhal Al-Mahāri) dan implementasinya dalam pembelajaran bahasa Arab. Penulis berharap penelitian ini dapat menambah khazanah pengetahuan bagi para pembaca dalam pendekatan pembelajaran bahasa Arab khususnya dalam pendekatan keterampilan.

\section{B. Pembahasan}

\section{Keterampilan Bahasa (Al-Mahārah Al-Lughawiyyah)}

Istilah keterampilan bahasa dapat disepadankan dengan istilah alMahārah al-Lughawiyyah. Ahmad 'Abduh 'Audh mendefinisikan Mahārah sebagai kemampuan yang berlandaskan pada pemahaman, dimana

\footnotetext{
${ }^{4}$ Hakan Aydoğan dan Azamat A. Akbarov, "The Four Basic Language Skills, Whole Language \& Intergrated Skill Approach in Mainstream University Classrooms in Turkey," Mediterranean Journal of Social Sciences 5, no. 9 (2014): 672, http://dx.doi.org/10.5901/mjss.2014.v5n9p672.

${ }^{5}$ Nasr D Abdrabo, "Integrated-Skills Approach: Teaching vs. Practice in L2 Acquisition," Defense Language Institute Foreign Language Center, 2014, 1-21.
} 
kemampuan tersebut didapat dari banyak latihan, pengulangan dan pemahaman. Sedangkan al-Mahärah al-Lughawiyyah adalah kemampuan dalam menggunakan bahasa dengan baik secara produktif maupun reseptif. ${ }^{6}$ Adapun dalam Kamus Besar Bahasa Indonesia (KBBI) kata keterampilan didefinisikan sebagai kecakapan untuk menyelesaikan tugas. Sedangkan keterampilan bahasa didefinisikan sebagai kecakapan seseorang untuk memakai bahasa dalam menulis, membaca, menyimak, atau berbicara. ${ }^{7}$ Dengan demikian keterampilan bahasa adalah kemampuan berbahasa yang meliputi kemampuan reseptif; menyimak dan membaca, dan kemampuan produktif; berbicara dan menulis.

Keterampilan berbahasa ada empat, yaitu menyimak (Istima'), berbicara (kalam), membaca (qira'ah), dan menulis (kitäbah). Ada dua model pengklasifikasian keempat keterampilan tersebut, yaitu oral (lisan) atau written (tulisan) dan receiving (reseptif) atau producing (produktif). ${ }^{8} \mathrm{Hal}$ senada juga dituliskan oleh Ahmad 'Abduh 'Audh dalam bukunya yang berjudul Madākhil Ta'līmul-lughah Al-'Arabiyyah bahwa mahārah diklasifikasikan menjadi dua model, yaitu (1) mahārah syafahiyyah (keterampilan lisan) yang meliputi istima' kalam dan mahārah mar'iyyah (keterampilan visual) yang meliputi qira'ah kitābah ; (2) mahārah intājiyyah (produktif) dan istī'äbiyyah (penyerapan). ${ }^{9}$ Dengan demikian oral dapat disepadankan dengan mahärah syafahiyyah, written dapat disepadankan dengan mahärah mar'iyyah, receiving dapat disepadankan dengan istī'ābiyyah, dan producing dapat disepadankan dengan mahārah intājiyyah. Sebagaimana gambar di bawah ini:

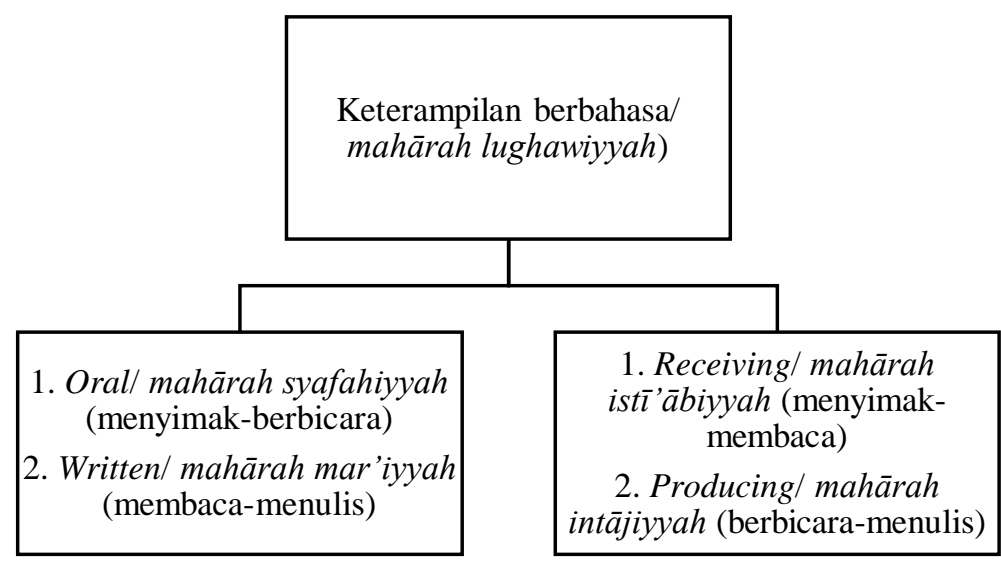

\footnotetext{
${ }^{6}$ Audh, Madakhil Ta'limul Lughah Al-Arabiyyah, 41.

${ }^{7}$ Departemen Pendidikan Nasional, Kamus Besar Bahasa Indonesia (Jakarta: PT Gramedia Pustaka, 2008), 1505.

${ }^{8}$ Aydoğan dan Akbarov, "The Four Basic Language Skills, Whole Language \& Intergrated Skill Approach in Mainstream University Classrooms in Turkey."

${ }^{9}$ Audh, Madakhil Ta'limul Lughah Al-Arabiyyah, 42.
} 
Dengan ini dapat dijelaskan bahwa; (1) menyimak adalah bentuk keterampilan reseptif di dalam mode oral; (2) berbicara adalah bentuk keterampilan produktif di dalam mode oral; (3) membaca adalah bentuk keterampilan reseptif di dalam mode written; (4) menulis adalah bentuk keterampilan produktif di dalam model written.

\section{Pendekatan (al-Madkhal)}

Kata pendekatan dalam Kamus Besar Bahasa Indonesia (KBBI) didefinisikan sebagai sebuah proses, cara, perbuatan mendekati. ${ }^{10}$ Sedangkan pendekatan dalam pembelajaran adalah titik tolak atau sudut pandang pengajar terhadap proses pembelajaran, yang merujuk pada pandangan tentang terjadinya suatu proses yang sifatnya masih sangat umum, masih filosofis, dan abstrak. Pendekatan pembelajaran, di dalamnya mewadahi, menginspirasi, menguatkan, dan melatari metode pembelajaran dengan cakupan teoritis tertentu. ${ }^{11}$ Istilah pendekatan dapat disepadankan dengan istilah al-Madkhal. Al-Madkhal secara bahasa berarti tempat masuk. Adapun secara istilah adalah seperangkat asumsi yang berkaitan dengan substansi bahasa dan pembelajaran bahasa. ${ }^{12}$ Sedangkan Mahmud Kamil An-Naqah mendefinisikan al-Madkhal sebagai sebuah kumpulan asumsi-asumsi yang berkaitan satu sama lain, dan juga memiliki hubungan erat dengan karakteristik bahasa dan karakteristik proses belajar mengajar bahasa. ${ }^{13}$ Sedangkan Zulhannan mendefinisikan pendekatan sebagai asumsi yang memiliki hubungan hierarkis dengan metode dan teknik pembelajaran, di samping saling melengkapi, dan ia bersifat aksiomatis, sedangkan metode bersifat prosedural, kemudian teknik merupakan aplikasi praktis atau operasional. ${ }^{14}$ Dengan demikian pendekatan dalam pembelajaran bahasa Arab merupakan seperangkat asumsi atau sudut pandang pengajar terhadap bahasa Arab dan pembelajarannya.

\section{Pendekatan Keterampilan (al-Madkhal al-Mahāri)}

Al-Madkhal al-Mahari adalah pendekatan dalam pembelajaran bahasa Arab yang berasumsi bahwa keempat keterampilan berbahasa; istima', kalam, qira'ah, dan kitābah adalah sebuah kesatuan yang memiliki hubungan satu sama lain. ${ }^{15}$ Dimana dalam pembelajaran bahasa Arab

\footnotetext{
${ }^{10}$ Departemen Pendidikan Nasional, Kamus Besar Bahasa Indonesia, 333.

${ }^{11}$ Maksudin dan Nurani, Pengembangan Kurikulum Pembelajaran Bahasa Arab (Teori dan Praktik), 15.

12 Zulhannan, Teknik Pembelajaran Bahasa Arab Interaktif (Jakarta: PT Raja Grafindo Persada, 2014), 79.

${ }^{13}$ Muhammad Kamil An-Naqah, Ta'lim Al-Lughah Al-'Arabiyah Lighairi Nathiqin biha: Asasuhu wa Madhakhiluhu wa Thuruqu Tadrisuhu (Makkah Al-Mukarramah: Jami'ah Umm Al-Qura, 1985), 43.

${ }^{14}$ Zulhannan, Teknik Pembelajaran Bahasa Arab Interaktif, 78.

${ }^{15}$ Audh, Madakhil Ta'limul Lughah Al-Arabiyyah, 42-43.
} 
keempatnya tidak boleh dipisahkan. Dalam literatur Inggris istilah ini dapat disepadankan dengan Integrated Skills Approach. Hal ini penulis tentukan atas dasar bahwa beberapa penelitian telah menggunakan istilah ini. Integrated Skills Approach adalah pendekatan dalam pembelajaran bahasa asing yang berasumsi bahwa pembelajaran keterampilan berbahasa listening, reading, speaking, dan writing tidak boleh dipisahkan satu sama lain dalam sistem pembelajaran bahasa Asing. ${ }^{16}$ Istilah ini kemudian dipertentangkan dengan istilah Segregated Skills Approach yang berasumsi bahwa keempat keterampilan berbahasa diajarkan secara terpisah. Sedangkan dalam literatur bahasa Indonesia, sepanjang yang penulis telusuri, belum ada istilah yang mewakili pendekatan ini.

Keempat keterampilan berbahasa tersebut saling berhubungan satu sama lain. Hal ini sebagaimana yang telah diungkapkan Ahmad 'Abduh 'Audh bahwa menulis berhubungan dengan membaca, menyimak berhubungan dengan berbicara, menyimak berhubungan dengan membaca, berbicara berhubungan dengan membaca, berbicara berhubungan dengan menulis, dan menyimak berhubungan dengan menulis. Mengajarkan membaca dan menulis tanpa memperhatikan keterampilan menyimak dan berbicara adalah hal yang tidak dapat dibenarkan. Karena keempatnya akan saling mempengaruhi satu sama lain. ${ }^{17}$

Hal senada juga diungkapkan oleh Sanchez bahwa (1) menulis berhubungan dengan keterampilan berbahasa lainnya. Misalnya ketika peserta didik akan menulis, maka ia akan menulis apa yang pernah ia baca, dengar, dan ucapkan baik kepada diri sendiri maupun orang lain; (2) menyimak berhubungan dengan keterampilan berbahasa lainnya. Menyimak dapat meningkatkan kemampuan berbicara. Semakin baik seseorang dalam memahami apa yang ia dengar, maka akan semakin baik pula kemampuan berbicaranya. Selain itu menyimak juga berhubungan dengan membaca. Keduanya terlibat dalam proses yang sama dan itu dapat meningkatkan kemampuan menulis; (3) membaca berhubungan dengan keterampilan berbahasa lainnya. Membaca juga berkaitan dengan menulis, hal ini terlihat dari semakin banyaknya seseorang membaca maka akan semakin baik tulisannya. Karena dalam membaca seseorang akan belajar bagaimana mempraktekkan tulisan yang baik; dan (4) berbicara berhubungan dengan keterampilan berbahasa lainnya. Berbicara adalah keterampilan produktif, maka saat melakukan kegiatan tersebut seseorang akan berbicara apa yang pernah ia dengar, baca, dan tulis. ${ }^{18}$

\footnotetext{
${ }^{16}$ Abdrabo, "Integrated-Skills Approach: Teaching vs. Practice in L2 Acquisition."

${ }^{17}$ Audh, Madakhil Ta'limul Lughah Al-Arabiyyah, 42-43.

${ }^{18}$ Abdrabo, "Integrated-Skills Approach: Teaching vs. Practice in L2 Acquisition."
} 
Melihat bahwa keempatnya saling berkaitan satu sama lain dalam pembelajaran bahasa, maka memisahkannya tentu akan menyulitkan dalam pembelajaran bahasa. Memisahkannya akan membatasi motivasi dan ketertarikan siswa dalam belajar bahasa. ${ }^{19}$ Pembelajaran bahasa yang hanya berkonsentrasi pada satu keterampilan saja seperti membaca atau menulis akan membingungkan dan menyesatkan peserta didik. ${ }^{20}$ Dalam beberapa kasus, memisahkan keempat keterampilan akan menjadikan pembelajaran bahasa asing kurang efektif karena dalam praktek komunikasi secara nyata keempat keterampilan tersebut tidak berperan secara terpisah. ${ }^{21}$ Oxford menyatakan bahwa ini adalah bentuk refleksi dari program pembelajaran bahasa asing tradisional. Pandangan tradisional ini berasumsi bahwa pembelajaran dengan memisahkan keterampilan bahasa akan lebih mudah dan tidak mungkin bagi peserta didik untuk berkonsentrasi pada lebih dari satu keterampilan dalam satu waktu. Meskipun hal itu dapat meningkatkan satu atau dua keterampilan bahasa, namun ini tidak cukup mampu menjamin peserta didik dapat terjun langsung ke dunia bahasa asing yang sesungguhnya. ${ }^{22}$ Hal ini menjadikan pembelajaran bahasa asing menjadi sempit bagi peserta didik, karena mereka hanya akan mengekspresikan kemampuan berbahasa asingnya ke dalam satu atau dua keterampilan saja. Sehingga keterampilan berbahasanya sulit untuk meningkat.

Dalam komunikasi secara nyata, keempat keterampilan tersebut tidak digunakan secara terpisah dan integrasi keempat keterampilan berbahasa pada hakikatnya digunakan dalam kehidupan sehari-hari. Pembelajaran bahasa asing di kelas hendaknya juga menyuguhkan situasi yang demikian selama proses pembelajaran bahasa asing. Adapun beberapa kelebihan yang didapat dari pendekatan keterampilan ini adalah ${ }^{23}$ :

a. Menyediakan pembelajaran yang lebih bermakna dan bertujuan jelas pada semua tingkatan.

b. Berkontribusi terhadap terciptanya pengajaran yang koheren dan terciptanya komunikasi yang lebih baik di dalam kelas.

c. Pengajar dapat memperkaya proses pembelajaran di kelas melalui pendekatan ini secara kooperatif.

\footnotetext{
${ }^{19}$ Abdrabo.

${ }^{20}$ Rebecca Oxford, Integrated Skills in the ESL/EFL Classroom (Washington: ERIC, 2001), https://eric.ed.gov/?id=ED456670.

${ }^{21}$ Eli Hinkel, "Integrating the Four Skills: Current and Historical Perspectives," The Oxford Handbook of Applied Linguistics, 2010, https://doi.org/10.1093/oxfordhb/9780195384253.013.0008.

${ }^{22}$ Oxford, Integrated Skills in the ESL/EFL Classroom.

${ }^{23}$ Selma Deneme dan Selen Ada, "An Application of Skills Integration in Language Teaching," Language In India 10 (2010): 9-18, http://languageinindia.com/sep2010/selmasecond.html.
} 
d. Peserta didik dapat belajar mengoperasikan dan mengatur keempat keterampilan bahasa dan mereka juga dapat dengan mudah mentransfer pengetahuan yang mereka dapat melalui suatu keterampilan bahasa ke area keterampilan bahasa yang lain.

e. Mempraktekkan keempat keterampilan bahasa akan mendorong peserta didik dalam belajar bahasa dan secara positif mampu mempengaruhi pengetahuan peserta didik terhadap bahasa kedua yang ia pelajari.

f. Pembelajaran bahasa asing dengan pendekatan ini akan mendekatkan peserta didik pada penggunaan bahasa dalam situasi nyata.

g. Dengan pendekatan ini, kelas akan memberikan input (menyimak dan membaca) tertentu yang akan menjadi dasar output (berbicara dan menulis) lebih lanjut. Dengan ini peserta didik dilibatkan dalam proses berbahasa secara utuh. ${ }^{24}$

Sedangkan beberapa kekurangan dari pendekatan ini antara lain adalah:

a. Pembelajaran yang berkonsentrasi pada satu keterampilan bahasa akan menjadikan pembelajaran menjadi lebih fokus dan intensif dengan kata lain, pembelajaran yang menggabungkan keempat keterampilan bahasa tidak akan fokus dan intensif pada sebuah keterampilan bahasa.

b. Praktek pendekatan ini membutuhkan waktu proses pembelajaran yang tidak singkat.

c. Pendekatan ini memiliki tuntutan lebih banyak baik kepada pengajar maupun peserta didik.

d. Dalam prakteknya, pendekatan ini membutuhkan pengajar yang multitalenta dan terlatih dengan baik.

e. Pendekatan ini tidak cukup praktis untuk diaplikasikan dalam kelas yang besar. $^{25}$

\section{Pendekatan Keterampilan (Al-Madhkal Al-Mahāri) dalam Pembelajaran Bahasa Arab}

Pendekatan ini berasumsi bahwa keterampilan berbahasa harus diajarkan dalam satu kesatuan. Dalam penerapannya para pengajar harus mampu mengintegrasikan keempatnya dalam proses pembelajaran. Eli Hinkel menjelaskan bahwa hendaknya kegiatan pembelajaran bisa menyajikan keterampilan menyimak dan membaca sebagai keterampilan reseptif untuk mendorong dan memfasilitasi keterampilan berbicara dan menulis. ${ }^{26} \mathrm{Hal}$ ini tentu menjadi tanggung jawab pengajar untuk dapat mengintegrasikan keempatnya dalam satu waktu.

\footnotetext{
${ }^{24}$ Miguel Angel Almarza Sanchez, "An Approach to the Integration of Skills in English Teaching," Didactica (Lengua y Literatura) 12 (2000): 21-41.

${ }^{25}$ Hinkel, "Integrating the Four Skills."

${ }^{26}$ Hinkel.
} 
Pendekatan ini berasumsi bahwa keterampilan berbahasa harus diajarkan dalam satu kesatuan. Dalam penerapannya para pengajar harus mampu mengintegrasikan keempatnya dalam proses pembelajaran. Eli Hinkel menjelaskan bahwa hendaknya kegiatan pembelajaran bisa menyajikan keterampilan menyimak dan membaca sebagai keterampilan reseptif untuk mendorong dan memfasilitasi keterampilan berbicara dan menulis. Hal ini tentu menjadi tanggung jawab pengajar untuk dapat mengintegrasikan keempatnya dalam satu waktu.

Para pengajar hendaknya melakukan sebuah riset tentang bagaimana keempat keterampilan dapat dimanfaatkan. Mereka juga harus didorong untuk dapat memilih bahan ajar dengan alat bantu audio visual yang dapat mendorong adanya integrasi keterampilan bahasa. Pembelajaran mungkin bisa dimulai dengan satu keterampilan bahasa, namun dalam prosesnya keempat keterampilan bahasa diintegrasikan menjadi satu. Para pengajar juga dituntut berpartisipasi aktif dalam proses pembelajaran, karena kondisi yang kondusif saat proses pembelajaran juga akan membantu tercapainya kesuksesan dalam belajar. ${ }^{27}$

Oxford mencontohkan tentang bagaimana seorang pengajar bahasa Inggris (sebagai bahasa asing) tetap kreatif meski tuntutan pembelajaran hanya meningkatkan satu keterampilan bahasa. Seorang pengajar mengajarkan keterampilan membaca untuk tingkat menengah, ia bisa saja memberikan instruksi secara lisan dengan menggunakan bahasa Inggris. Dengan ini peserta didik akan mengasah keterampilan menyimaknya untuk memahami instruksi tersebut. Dalam proses pembelajarannya, peserta didik dapat mendiskusikan bacaannya, sehingga mereka akan menggunakan keterampilan berbicara dan menyimak. Setelah itu peserta didik diminta untuk membuat sebuah rangkuman atau analisis terhadap bacaan tersebut dan dituangkan dalam tulisan, hal ini tentu akan mengasah kemampuan menulisnya. ${ }^{28}$ Dalam contoh yang dipaparkan Oxford ini, keempat keterampilan dapat difasilitasi secara bersamaan dalam sebuah kelas.

Oxford mencontohkan tentang bagaimana seorang pengajar bahasa Inggris (sebagai bahasa asing) tetap kreatif meski tuntutan pembelajaran hanya meningkatkan satu keterampilan bahasa. Seorang pengajar mengajarkan keterampilan membaca untuk tingkat menengah, ia bisa saja memberikan instruksi secara lisan dengan menggunakan bahasa Inggris. Dengan ini peserta didik akan mengasah keterampilan menyimaknya untuk memahami instruksi tersebut. Dalam proses pembelajarannya, peserta didik

${ }^{27}$ Aneela Akram dan Ameela Malik, "Integration of Language Learning Skills in Second Language Acquisition," International Journal of Arts and Sciences 3, no. 14 (2010): 231, http://www.openaccesslibrary.org/images/PRV127_Aneela_Akram.pdf.

28 Oxford, Integrated Skills in the ESL/EFL Classroom. 
dapat mendiskusikan bacaannya, sehingga mereka akan menggunakan keterampilan berbicara dan menyimak. Setelah itu peserta didik diminta untuk membuat sebuah rangkuman atau analisis terhadap bacaan tersebut dan dituangkan dalam tulisan, hal ini tentu akan mengasah kemampuan menulisnya. Dalam contoh yang dipaparkan Oxford ini, keempat keterampilan dapat difasilitasi secara bersamaan dalam sebuah kelas.

\section{Kesimpulan}

Pendekatan keterampilan merupakan pendekatan yang berasumsi bahwa keempat keterampilan berbahasa; menyimak, berbicara, membaca, menulis merupakan satu kesatuan yang tidak dapat dipisahkan dalam proses pembelajaran bahasa terutama dalam pembelajaran bahasa asing. Maka dengan menggunakan pendekatan ini, peserta didik akan dilatih dan dihadapkan pada penggunaan bahasa Arab yang utuh, baik reseptif maupun produktif tanpa harus terfokus pada satu keterampilan berbahasa saja. Pendekatan ini memiliki beberapa kelebihan dan kekurangan, di antaranya dapat mendekatkan peserta didik pada situasi berbahasa dalam dunia nyata, selain itu peserta didik juga dapat belajar mengatur keempat keterampilan berbahasa dan mentransfer pengetahuan dari satu keterampilan ke keterampilan lain. Tetapi, pendekatan ini juga membutuhkan pengajar multitalenta dan terlatih dengan baik serta sulit diterapkan dalam kelas besar.

Melihat realita pembelajaran bahasa Arab saat ini yang kering akan praktek-praktek keterampilan berbahasa, pendekatan keterampilan ini perlu diterapkan dalam pembelajaran bahasa Arab. Menggunakan pendekatan ini akan melatih peserta didik untuk berbahasa secara nyata, karena pada hakikatnya keempat keterampilan berbahasa saling berkaitan satu sama lain. Dalam mengimplementasikan pendekatan ini pengajar hendaknya dapat memfasilitasi dan meningkatkan keempat kemampuan berbahasa dalam kelas, dengan cara memilih bahan ajar dan media pembelajaran yang dapat mengintegrasikan keempatnya. Penelitian ini mendeskripsikan pendekatan keterampilan, kelebihan dan kekurangannya serta implementasinya. Namun penulis memandang masih perlu adanya penelitian lanjutan mengenai implementasi pendekatan keterampilan ini secara lebih detail dan mendalam. 


\section{Daftar Pustaka}

Abdrabo, Nasr D. "Integrated-Skills Approach: Teaching vs. Practice in L2 Acquisition." Defense Language Institute Foreign Language Center, 2014, 1-21.

Akram, Aneela, dan Ameela Malik. "Integration of Language Learning Skills in Second Language Acquisition." International Journal of Arts and Sciences 3, no. 14 (2010): 231.

http://www.openaccesslibrary.org/images/PRV127_Aneela_Akram. pdf.

An-Naqah, Muhammad Kamil. Ta'lim Al-Lughah Al-'Arabiyah Lighairi Nathiqin biha: Asasuhu wa Madhakhiluhu wa Thuruqu Tadrisuhu. Makkah Al-Mukarramah: Jami'ah Umm Al-Qura, 1985.

Audh, Ahmad Abdul. Madakhil Ta'limul Lughah Al-Arabiyyah. Makkah AlMukarramah: Jami'ah Umm Al-Qura, 2000.

Aydoğan, Hakan, dan Azamat A. Akbarov. "The Four Basic Language Skills, Whole Language \& Intergrated Skill Approach in Mainstream University Classrooms in Turkey." Mediterranean Journal of Social Sciences 5, no. 9 (2014): 672.

http://dx.doi.org/10.5901/mjss.2014.v5n9p672.

Deneme, Selma, dan Selen Ada. "An Application of Skills Integration in Language Teaching." Language In India 10 (2010): 9-18. http://languageinindia.com/sep2010/selmasecond.html.

Departemen Pendidikan Nasional. Kamus Besar Bahasa Indonesia. Jakarta: PT Gramedia Pustaka, 2008.

Hinkel, Eli. "Integrating the Four Skills: Current and Historical Perspectives." The Oxford Handbook of Applied Linguistics, 2010. https://doi.org/10.1093/oxfordhb/9780195384253.013.0008.

Kridalaksana, Harimurti. Kamus Linguistik. Jakarta: PT Gramedia, 2008. Maksudin, dan Qoim Nurani. Pengembangan Kurikulum Pembelajaran Bahasa Arab (Teori dan Praktik). Yogyakarta: Lesfi, 2018.

Oxford, Rebecca. Integrated Skills in the ESL/EFL Classroom. Washington: ERIC, 2001. https://eric.ed.gov/?id=ED456670.

Sanchez, Miguel Angel Almarza. "An Approach to the Integration of Skills in English Teaching." Didactica (Lengua y Literatura) 12 (2000): 21-41. Zulhannan. Teknik Pembelajaran Bahasa Arab Interaktif. Jakarta: PT Raja Grafindo Persada, 2014. 
242 | Muna Nabila Amatullah, Novi Kusumaningrum 